\title{
Front Matter: Volume 11930
}

, "Front Matter: Volume 11930," Proc. SPIE 11930, International Conference on Mechanical Engineering, Measurement Control, and Instrumentation, 1193001 (14 October 2021); doi: 10.1117/12.2617259

SDIE Event: International Conference on Mechanical Engineering, Measurement SPIE. Control, and Instrumentation (MEMCl 2021), 2021, Guangzhou, China 


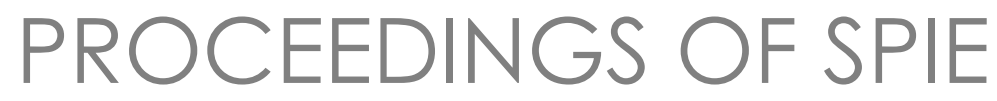

\title{
International Conference on Mechanical Engineering, Measurement Control, and Instrumentation
}

\author{
Guixiong Liu \\ Siting Chen \\ Editors
}

16-18 July 2021

Guangzhou, China

Organized by

Guangdong Measurement and Control Technology and Equipment Application Promotion Association (China)

Sponsored by

AEIC Academic Exchange Information Centre (China)

Sponsored and Published by

SPIE

Volume 11930

Part One of Two Parts 
The papers in this volume were part of the technical conference cited on the cover and title page. Papers were selected and subject to review by the editors and conference program committee. Some conference presentations may not be available for publication. Additional papers and presentation recordings may be available online in the SPIE Digital Library at SPIEDigitalLibrary.org.

The papers reflect the work and thoughts of the authors and are published herein as submitted. The publisher is not responsible for the validity of the information or for any outcomes resulting from reliance thereon.

Please use the following format to cite material from these proceedings:

Author(s), "Title of Paper," in International Conference on Mechanical Engineering, Measurement Control, and Instrumentation, edited by Guixiong Liu, Siting Chen, Proc. of SPIE 11930, Seven-digit Article CID Number (DD/MM/YYYY); (DOI URL).

ISSN: 0277-786X

ISSN: 1996-756X (electronic)

ISBN: 9781510647282

ISBN: 9781510647299 (electronic)

Published by

SPIE

P.O. Box 10, Bellingham, Washington 98227-0010 USA

Telephone +1 3606763290 (Pacific Time)

SPIE.org

Copyright (C) 2021 Society of Photo-Optical Instrumentation Engineers (SPIE).

Copying of material in this book for internal or personal use, or for the internal or personal use of specific clients, beyond the fair use provisions granted by the U.S. Copyright Law is authorized by SPIE subject to payment of fees. To obtain permission to use and share articles in this volume, visit Copyright Clearance Center at copyright.com. Other copying for republication, resale, advertising or promotion, or any form of systematic or multiple reproduction of any material in this book is prohibited except with permission in writing from the publisher.

Printed in the United States of America by Curran Associates, Inc., under license from SPIE.

Publication of record for individual papers is online in the SPIE Digital Library.

\section{SPIE. DIGITAL}

Paper Numbering: A unique citation identifier (CID) number is assigned to each article in the Proceedings of SPIE at the time of publication. Utilization of CIDs allows articles to be fully citable as soon as they are published online, and connects the same identifier to all online and print versions of the publication. SPIE uses a seven-digit CID article numbering system structured as follows:

- The first five digits correspond to the SPIE volume number.

- The last two digits indicate publication order within the volume using a Base 36 numbering system employing both numerals and letters. These two-number sets start with 00, 01, 02, 03, 04, 05, 06, 07, 08, 09, OA, OB ... 0Z, followed by 10-1Z, 20-2Z, etc. The CID Number appears on each page of the manuscript. 


\section{Contents}

\section{Part One}

\section{ELECTRONIC IMAGING AND OPTO-MECHANICAL DESIGN}

$1193002 \quad$ Maintenance method of large machine tool ball screw wear based on brush plating technology and precision grinding technology [11930-100]

1193003 Experimental study on axial bending force of elevator wire rope [11930-124]

$1193004 \quad$ Research on fuzzy security evaluation of power battery system with thermal runaway test by GRA and entropy method [11930-132]

1193005 Modeling and stability analysis of power system with SVC considering harmonic coupling characteristics [1 1930-147]

1193006 Probabilistic assessment of transformer operating risk considering the correlation among wind power, PV and load [1 1930-162]

1193007 The optimal method of distributed power grid connection considering demand-side participation [11930-25]

1193008 Development of engineering structure intelligent monitoring system based on LoRa [1 1930-40]

1193009 Damage monitoring experiment on diagonal pressure pipe based on distributing optical fiber [11930-50]

11930 OA Model investigation of a tidal current turbine for rivers [1 1930-60]

11930 OB Failures originated from defects of IGBTs used for electrical power application [1 1930-66]

11930 OC Dynamic simulation analysis of boom falling accident of portal crane [11930-70]

11930 OD Safety performance analysis of container gantry crane lifting leg [11930-73]

11930 OE Research on kinematic characteristics of flexible bearing for harmonic reducer [11930-98]

11930 OF Design and test of hand-carried air-assisted electrostatic sprayer [11930-103]

11930 OG Design of image acquisition system of online verification device for ship engine spare parts packing [1 1930-104]

$11930 \mathrm{OH} \quad$ A multitask-based flexible networking and resource scheduling algorithm for UAV swarm [11930-108] 
11930 Ol Super-resolution reconstruction method of transmission line key components image based on SRGAN [1 1930-1 12]

11930 OJ Remaining useful life prediction of bearing based on autoencoder-LSTM [1 1930-127]

11930 OK Commutation failure suppression strategy of HVDC transmission system based on deep double Q-Network [1 1930-129]

$11930 \mathrm{OL} \quad$ Research on the influence of moisture immersion on the electric field distribution of composite insulator with interface defects [11930-13]

11930 OM Research on multi-exposure image fusion algorithm based on detail enhancement [11930-137]

11930 ON Research on estimation method of starting voltage of power battery in high power laser system [11930-142]

1193000 Applications of NSST enhancement based on adaptive longicorn optimized segmentation and improved modulus in infrared image of electrical equipment [11930-149]

11930 OP Infrared image enhancement algorithm based on seagull optimized Otsu and BEEPS algorithm in NSST domain [11930-150]

$119300 Q \quad$ Infrared image of electrical equipment enhancement using grey wolf adaptive nonlocal mean denoising and adaptive fuzzy enhancement [1 1930-153]

11930 OR The field-circuit coupled physical simulation of open boundary electric field [1 1930-17]

11930 OS Fault section identification of distribution network based on zero sequence current distribution characteristics [1 1930-20]

11930 OT Thermoelectric structural field coupling simulation of ideal electrical contact model [11930-23]

11930 OU Comprehensive optimization method of short-circuit current restriction measures considering safety efficiency and cost [11930-26]

$11930 \mathrm{OV} \quad$ The research and implementation of intelligent power management system based on MCU [1 1930-37]

11930 OW Numerical simulation method for wrinkle defect of automobile panel [1 1930-4]

11930 OX Study on nitriding enhancement technology of lifts safety gear wedge [11930-5]

11930 OY Analysis of driving safety factors in urban tunnels based on ergonomics [11930-62]

$119300 Z$ Application of finite element analysis in local stability check of main girder of bridge crane [11930-69]

$1193010 \quad$ Relay protection communication model based on 2M optical interface [1 1930-7] 
1193011 Study on influence of reinforcement ring clearance on strength and stiffness performance of expansion joint [11930-75]

1193012 Research on DC resonance mechanism and suppression measures of modular multilevel DC ice melting device [11930-78]

1193013 Zero voltage ride through state judgement method for renewable power generation system based on terminal current [11930-8]

1193014 Study on overvoltage characteristics of lightning intrusion wave in 500kV GIS substation [11930-85]

1193015 Research on debugging technology and safety management of relay protection device [11930-86]

1193016 Design of small corn peeling harvester [11930-164]

\section{SENSING TECHNOLOGY AND MEASUREMENT CONTROL APPLICATIONS}

1193017 Research on damage identification of highway bridge [11930-10]

1193018 Research on the Influence of slope and heat release rate on the critical velocity of straddle monorail tunnel [11930-105]

1193019 The design experiment and simulation of parallelogram micro-low gravity balance device with adjustable spring [1 1930-11]

$119301 \mathrm{~A}$ Signal transmission method of wireless ad hoc network in complex cable channel environment [11930-115]

$119301 \mathrm{~B} \quad$ Research on positioning method of reinforcement in reinforced concrete based on magnetic induction detection [11930-133]

11930 1C Analysis of dynamic characteristics of parallelogram institution with series springs under impact load based on Adams [11930-14]

11930 1D Current trajectory control of induction motor based on MATLAB [11930-143]

$119301 \mathrm{E} \quad$ Multi branches dilated CNN federated learning for transmission line fault diagnosis [1 1930-146]

$11930 \mathrm{lF} \quad$ Study on force-chain-resistance network structure of pressure control granular material [11930-18]

11930 1G Research on landslide control technology of transmission line tower foundation [11930-28]

$119301 \mathrm{H} \quad$ Design of multi-lane line detection algorithm based on semantic segmentation and clustering [11930-3] 
$1193011 \quad$ Development of a crystal oscillator taming module based on PID control algorithm [1 1930-39]

$119301 \mathrm{~J} \quad$ Magnetic anomaly signal detection using adaptive stochastic resonance system [1 1930-41]

$119301 \mathrm{~K} \quad$ Variable inertia virtual synchronous control strategy for cascaded H-bridge grid-connected inverter [1 1930-52]

$119301 \mathrm{~L} \quad$ Smoke sensor for intelligent power distribution room [11930-56]

$119301 \mathrm{M}$ Detailed explanation of brushless DC motor control and power MOSFET drive application [1 1930-65]

$119301 \mathrm{~N} \quad$ Airborne gravimetry and error compensation based on the undulating flight of UAV [1 1930-72]

1193010 Design and calibration experiment of six-dimensional force sensor for heavy-duty manipulator [1 1930-94]

$119301 \mathrm{P} \quad$ An improved detection method of metal product surface damage based on super-resolution reconstruction [11930-95]

$119301 Q \quad$ Channel transmission fault detection method for smart grid based on multivariate data analysis [11930-106]

$119301 \mathrm{R} \quad$ Design of integrated fire protection system for building electrical fire based on multi-sensor data fusion [1 1930-107]

11930 is Calculation of distribution elliptical of the longitudinal torch community point for a certain type special incendiary bomb [11930-110]

$119301 \mathrm{1T} \quad$ Application of ground penetrating radar to fault analysis in construction of grounding device [11930-111]

$119301 \mathrm{D}$ Design of a fast on-line measurement device for deflection of assembly car body based on wireless laser sensing [11930-123]

$119301 \mathrm{~V} \quad$ Method of rebar detection in cement pole based on BP neural network [11930-125]

\section{Part Two}

11930 1W Research on fuzzy logic control allocation of missile compound control system [11930-130]

$119301 X \quad$ Research on GIS partial discharge location and monitoring system based on loop signal circle [11930-138]

$119301 Y \quad$ A kind of small omnidirectional antenna for EMC measurement [1 1930-141]

1193012 Design of power quality abnormal data identification and verification system [1 1930-158] 
1193020 Development and experimental verification of physical platform for single station flexible DC converter valve [11930-159]

$1193021 \quad$ Influence analysis of pipe parameters of double elbow of fish suction device on pipe flow field based on liquid-solid coupling [11930-19]

1193022 Research on the model predictive control strategy of VSC rectifier station connected to wind farm [1 1930-29]

1193023 Comprehensive application of leakage detection technology in subway deep foundation pit [11930-30]

1193024 Research on soft sensing method of pumping unit system efficiency based on KPCA and SVR [11930-33]

$1193025 \quad$ Ultrasonic inspection of S line of 7050 aluminum alloy friction stir welding [1 1930-42]

1193026 Design of wavelength-locking module for VCSEL [1 1930-44]

1193027 Multi-modal sensing positioning technology for intelligent verification of stacked kilogram weights [1 1930-45]

1193028 Integrated robotic measurement and machining technology for large castings [11930-61]

1193029 Study on wave propagation of dynamic compaction for ground improvement by considering nearby oil pipeline [11930-68]

$119302 \mathrm{~A}$ Research and design of the information collection system of human life characteristics [11930-74]

$119302 B \quad$ An improved distortion feature information restoration method [1 1930-80]

11930 2C Small crack detection method for cylinder block based on improved SSD model research [11930-83]

$119302 \mathrm{D}$ Research on fault monitoring technology of station-use low-voltage AC distribution system [11930-84]

$119302 \mathrm{E}$ The accurate recognition system of citrus flowers using YOLOv4-Tiny lightweight neural network and FPGA embedded platform [1 1930-89]

$119302 \mathrm{~F} \quad$ Analysis of abnormal running behavior of mechanical operators based on sensor detection [11930-9]

$119302 \mathrm{G}$ Effect of inlet temperature on $\mathrm{CO}_{2}$ heat transfer at supercritical pressure in vertical upward flow [11930-90]

$119302 \mathrm{H} \quad$ Research on the critical impact velocity of droplets impacting metal grid and breaking into sub-droplets [11930-96] 
$1193021 \quad$ Capacity and energy test analysis of lithium-ion traction battery pack for high energy applications [11930-97]

11930 2J One hypersonic unmanned aerial vehicle sensor failure controller design [11930-128]

\section{INTELLIGENT INSTRUMENTATION AND AUTOMATION EQUIPMENT}

$119302 \mathrm{~K}$ Design of sunflower double row planting film mulching machine [11930-101]

$119302 \mathrm{~L} \quad$ A new design of sound-absorbing structure for prefabricated substation [11930-134]

$119302 \mathrm{M}$ Vibration simulation and test of shunt reactor under DC bias [11930-135]

$119302 \mathrm{~N}$ Study of application of composite sampling and improved LightGBM algorithm to the diagnosis of unbalanced transformer fault samples [11930-139]

1193020 A kind of intelligent tunable EMI filter [11930-140]

11930 2P Design of DC filter for 24-pulse high power rectifier [1 1930-145]

$119302 Q \quad$ Electromagnetic coupling prediction for the low voltage wire harness of electric vehicle [11930-15]

$119302 R \quad$ A novel AEDL network and its application in performance degradation assessment of rolling bearings [11930-152]

$1193025 \quad$ Remote interaction system of substation based on mobile terminal [1 1930-154]

11930 2T Parameter optimization design of electric vehicle wireless charging system based on rectifier bridge input impedance analysis [1 1930-157]

$119302 \mathrm{U}$ Transient analysis of dual active bridges under short circuit at load side [11930-16]

$119302 \mathrm{~V}$ Comparative analysis of resistance models for slurries pipeline transportation [1 1930-2]

11930 2W Discharge fault diagnosis model for transformers based on free characteristic gas [1 1930-21]

$119302 X \quad$ Research on equipment identification technology of power monitoring system [11930-22]

$119302 Y \quad$ Minimization of entropy generation rate in reverse water gas shift reactor with linear phenomenological heat transfer law [11930-36]

$1193022 \quad$ A class of deployable polyhedral mechanisms based on the loop-closed mechanism [11930-43] 
1193030 Research on grid-connected stability control of full-power conversion wind turbine controlled by grid-side converter coupling voltage [11930-51]

$1193031 \quad$ Energy efficiency test and classification for escalator [1 1930-54]

1193032 Research on standardized assembly process method of aircraft cables [11930-59]

1193033 Safety evaluation and application for driving system of escalator [11930-64]

1193034 Development of intelligent verification system for stacked kilogram weights [1 1930-67]

1193035 Production of entropy minimization of $\mathrm{CO}_{2}$ hydrogenation to light olefins unit reactor with linear phenomenological heat transfer law [11930-76]

1193036 Test system design of container RFID tag based on virtual instrumentation [1 1930-77]

1193037 Research on bearing health state prediction based on multidimensional information average convolutional neural network [11930-79]

$1193038 \quad$ Unified admittance modeling of grid-connected converter and stability analysis for convertergrid system [11930-82]

1193039 Research on design and application of temporary line protection device in power system [11930-93]

11930 3A Design of output matching network for marine solar batteries based on embedded development technology [11930-1]

11930 3B Temperature field analysis of cable joint [11930-102]

11930 3C The effect of exhaust gas recirculation on engine combustion [11930-114]

11930 3D Testing device and method of escalator stopping distance based on infrared technology [11930-122]

11930 3E A fault analysis of ammunition supply system for a certain type of vehicle [1 1930-12]

$119303 \mathrm{~F} \quad$ The branch current method zinc oxide arrester power frequency parameter field test method and its system and test [11930-131]

$1193036 \quad$ Application of spacecraft manufacturing equipment management system [11930-136]

$119303 \mathrm{H} \quad$ Development of new wave-eliminating interceptor in the tunnel engineering [1 1930-148]

$1193031 \quad$ The intelligent anti-mistake system for combination of primary and secondary equipment [11930-156]

11930 3J An integrated on-board charger (OBC) with high power density and efficiency for electric vehicle [11930-160] 
11930 3K Research on PEMFC and its interface converter [11930-161]

$119303 \mathrm{~L} \quad$ Arc contacts ablation state assessment method based on machine learning multiple linear regression [11930-24]

$119303 \mathrm{M} \quad$ Study on the fire-resistance of UHV converter station [1 1930-27]

$119303 \mathrm{~N} \quad$ Calculation and analysis on transmission performance of slotted permanent magnetic coupler [1 1930-32]

1193030 Design and motion research of self-rotating double-body negative pressure wall climbing robot [1 1930-35]

11930 3P Intelligent industrial vortex flowmeter based on MSP430 [1 1930-38]

$119303 Q \quad$ A visual auxiliary inventory counting system for the automated stereoscopic warehouse [1 1930-49]

11930 3R Wind power prediction of CNN-LSTM network model based on unsupervised algorithm processing [11930-53]

$1193035 \quad$ Gearbox fault diagnosis based on deep convolution generative adversarial network [1 1930-55]

11930 3T Key technology of estimating earthwork volume of riprap project by cross-section survey [11930-57]

$119303 \mathrm{U} \quad$ A quick capacity estimation method for Li-ion battery combining equivalent circuit model and Bayesian network [1 1930-6]

11930 3V Analysis of anti-wave characteristics of a new type of solar farming platform [1 1930-81]

11930 3W Multi-objective optimization of hybrid energy storage in micro-grid based on wavelet packet decomposition and neural network [11930-34]

$119303 X \quad$ Design of peanut sowing spraying film covering machine [11930-170] 